\title{
Managing conflict and trust as coopetition within alliance partnerships in an emerging economy
}

\begin{tabular}{|c|c|}
\hline \multicolumn{2}{|c|}{$\begin{array}{l}\text { Authors: } \\
\text { Hao Shen }^{1} \text { (1) } \\
\text { Yu Gao }{ }^{1} \\
\text { Chenlu Zhang }\end{array}$} \\
\hline \multicolumn{2}{|c|}{$\begin{array}{l}\text { Affiliations: } \\
{ }^{1} \text { School of Economics and } \\
\text { Finance, Xi'an Jiaotong } \\
\text { University, Xi'an, China }\end{array}$} \\
\hline \multicolumn{2}{|c|}{$\begin{array}{l}{ }^{2} \text { Department of Business } \\
\text { Administration, School of } \\
\text { Economic and Management, } \\
\text { Northwest University, Xi'an, } \\
\text { China }\end{array}$} \\
\hline \multicolumn{2}{|c|}{$\begin{array}{l}\text { Corresponding author: } \\
\text { Chenlu Zhang, } \\
\text { drizzlezhang0821@163.com }\end{array}$} \\
\hline \multicolumn{2}{|c|}{$\begin{array}{l}\text { Dates: } \\
\text { Received: } 08 \text { Oct. } 2018 \\
\text { Accepted: } 26 \text { Apr. } 2019 \\
\text { Published: } 01 \text { July } 2019\end{array}$} \\
\hline \multicolumn{2}{|c|}{$\begin{array}{l}\text { How to cite this article: } \\
\text { Shen, H., Gao, Y. \& Zhang, C. } \\
\text { (2019) Managing conflict and } \\
\text { trust as coopetition within } \\
\text { alliance partnerships in an } \\
\text { emerging economy. } \\
\text { South African Journal of } \\
\text { Business Management 50(1), } \\
\text { a467. https://doi.org/10. } \\
4102 / \text { sajbm.v50i1.467 }\end{array}$} \\
\hline \multicolumn{2}{|c|}{$\begin{array}{l}\text { Copyright: } \\
\text { (C) 2019. The Authors. } \\
\text { Licensee: AOSIS. This } \\
\text { is licensed under the } \\
\text { Creative Commons } \\
\text { Attribution License. }\end{array}$} \\
\hline \multicolumn{2}{|l|}{ Read online: } \\
\hline 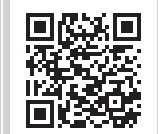 & $\begin{array}{l}\text { Scan this QR } \\
\text { code with your } \\
\text { smart phone or } \\
\text { mobile device } \\
\text { to read online. }\end{array}$ \\
\hline
\end{tabular}

Background: Trust and conflict represent the critical foundation characterising the inter-firm relationship of cooperation and competition, and their co-existence as coopetition within an alliance partnership. The literature has often regarded conflict and trust as uni-dimensional variables to clarify their interactive influences. However, few studies has explicitly investigate how these two opposite forces and their sub-dimensions may interact and create synergic effects in alliance partnerships in emerging economies.

Objectives: This study applies a coopetition perspective to articulate the complex interactive nature of conflict and trust between partners, aiming at revealing how specific patterns of conflict (task and emotional) and trust (cognitive and affective) interact with each other in impacting the focal firm's performance within the alliance partnership.

Method: Using survey data collected from 490 sampled firms in China, we ran three regression models to test four hypotheses from the interactive matrix between different dimensions of conflict and trust.

Results: The results indicate that the coupled pattern (the interaction between emotional conflict and affective trust) and the compatible pattern (the interaction between task conflict and cognitive trust) could improve firm performance, whereas the dysfunctional pattern (the interaction between emotional conflict and cognitive trust) and the mismatched pattern (the interaction between task conflict and affective trust) could harm firm performance within alliance partnerships.

Conclusion: The new findings imply diverse ways to combine conflict and trust to achieve the best synergistic effect for allied firms in emerging economies, and thus extend and enrich the literature by providing contextual knowledge regarding 'conflict and trust as coopetition phenomena' in relevant fields.

Keywords: Coopetition; alliance partnerships; trust; conflict; emerging economy.

\section{Introduction}

Strategic alliances are critical sustainable cooperative arrangements between two or more firms that improve the firms' competitive position and performance (Ireland, Hitt, \& Vaidyanath, 2002), making alliance partnership governance a critical facilitator of firm success in emerging economies like China (Li, Jiang, Pei, \& Jiang, 2017). Because of the high level of competition and the scarcity of resources in these fast-growing economies, firms pursue joint efforts to create common value and seek private actions to appropriate private value across inter-partner cooperation (Das \& Teng, 2000). Thus, a firm that is involved in both cooperative and competitive relationships would experience collaboration and competition within an alliance partnership simultaneously, which is referred to as coopetition (Bengtsson \& Kock, 1999, 2000, 2014; Brandenburger \& Nalebuff, 1996; Luo, 2007). The literature on alliance governance has suggested that trust is the foundation of inter-partner cooperation as it manages tensions arising from inter-partner conflict that results from competition (De Man \& Roijakkers, 2009). Accompanying the simultaneous occurrence of cooperation and competition, trust and conflict represent the critical foundation characterising the inter-firm relationship of cooperation and competition, and their co-existence as coopetition within an alliance partnership. The literature has found that trust and conflict vary considerably in their psychological or behavioural attributes across partnerships and that the paradoxical patterns resulting from their interaction created tensions and dynamic effects (Park, Srivastava, \& Gnyawali, 2014; Peterson \& Behfar, 2003; Rau, 2005), which have an important impact on a firm's performance (Parayitam \& Dooley, 2009). 
The literature has often regarded conflict and trust as unidimensional variables to clarify the interactive influences, which fails to reveal the complexities of conflict-trust interactions as the holistic and dynamic balance in the logic of coopetition. For example, a firm must confront the threat of conflict from its partners in alliance partnerships (De Dreu, 2006). Firms can leverage specific patterns of cooperation (e.g. trust) to reduce the negative effect of interpartner conflict or even to strengthen its potentially positive effect (Jehn, 1997). Moreover, trust between partners can be framed as an effective mechanism that interacts with conflict to create synergy in alliance partnerships (Peterson \& Behfar, 2003; Rau, 2005). Therefore, traditional approaches that focus on trust-based and conflict-based governances individually fail to reveal the complex nature of coopetition between partners and the effects of trust and conflict in coopetition on the performance. Some studies have recognised the interplay between conflict and trust in coopetition in advanced economies (Panteli \& Sockalingam, 2005; Parayitam \& Dooley, 2007, 2009), but they focus on the positive aspects of conflict-trust interactions, leaving their negative side and their 'double-edged sword' effect untouched. In addition, the previous literature was conducted mainly in the setting of advanced economies, and little has been revealed regarding whether the conclusions could be extended into emerging economies. Consequently, the theoretical gaps limit us to efficiently manage alliance partnerships by balancing conflict and trust in a synergic manner to affect firm performance in emerging economies. More importantly, previous studies (e.g. McAllister, 1995; Rose \& Shoham, 2004; Rose, Shoham, Neill, \& Ruvio, 2007) have conceptually divided conflict and trust into different dimensions (i.e. task conflict and emotional conflict, cognitive trust and affective trust),but few studies have explicitly investigate how these two opposite forces and their sub-dimensions may interact and create synergic effects for alliance partnerships in emerging economies.

To address these gaps, this study applies a coopetition perspective to interpret the complex interactive nature of conflict and trust between partners and explores how specific types of conflict (task and emotional) and of trust (cognitive and affective) would interact with each other and affect firms' performance within alliance partnerships in emerging economies. Using data from 490 manufacturing firms in China, this study empirically examined the effects of different types of conflict-trust interactions on the focal firm's performance.

Our theoretical discussion and empirical results would add to prior literature in three important ways. Firstly, different from the 'paradox as problem' view that previous research adopts, our research employs a 'trans-paradox as solution' perspective to delineate the nature, diversity and dynamics of the trust-conflict interaction, going beyond the 'moderating role' that trust and conflict play in affecting firm performance with the 'positive or negative' functional paradigm, and achieves a more holistic understanding regarding the trustconflict issue in firm alliance. Secondly, our research, based on the partitioning of the trust and conflict construct, illustrates how two opposite elements (i.e. conflict and trust), because of their inherent sub-dimensional nature, would be partially complementary (positive) if properly matched but partially contradictory (negative) if improperly combined, and thus highlight the duality of trust-conflict interaction as equally co-existent in unity with 'double-edged sword' effects contingent on their sub-dimensions. Thirdly, this study provides critical contextual knowledge about how conflict and trust interact to impact firm performance, implying that the theoretical research has to pay more attention to the recognition and management of conflict-based and trust-based coopetition within an alliance partnership in emerging economies.

\section{Theoretical background and framework \\ Conflict and trust within an alliance partnership}

Conflict and trust have been extensively addressed in different theoretical fields such as organisational behaviour, firm networking, innovation and strategic alliance $(\mathrm{Wu}, \mathrm{Zhao}$, $\&$ Zuo, 2017). The large body of literature has recognised the theoretical foundation and the sub-dimensions of trust and conflict. In the alliance literature, conflict, which refers to 'multi-dimensional, potentially beneficial, and either functional or dysfunctional, depending on the focus of the debate and the source of the disagreement between the parties behaviours by one party that impede/inhibit the attainment of another party's goals' (Rose et al., 2007, p. 1), has been deemed as a complex social and psychological phenomenon during inter-partner interactions. Two dimensions of conflict have been identified: task conflict (or cognitive conflict) and emotional conflict (or affective conflict) (Jehn, 1995; Panteli \& Sockalingam, 2005; Rose \& Shoham, 2004; Rose et al., 2007). Task conflict arises from 'the perception of disagreements about the content differences in viewpoints, ideas and opinions'(Parayitam \& Dooley, 2009 , p. 1). Because task conflict involves mutually analysing and understanding between two partners, it may facilitate information sharing (Yang, Gao, Li, Shen, \& Zheng, 2017), creativeness enhancement (Yen, Abosag, Huang, \& Bang, 2017) and the implementation of team decisions (Wit, Jehn, \& Scheepers, 2016), which results in a more thorough consideration of multiple factors (Hood, Cruz, \& Bachrach, 2017; Rose et al., 2007). In contrast, emotional conflict arises from 'interpersonal tensions and is largely emotional in nature'(Parayitam \&Dooley, 2009, p. 1), centring on disagreements between parties and resulting in the negative and dysfunctional impact of conflict on team and organisational functioning as it promotes inefficiency and ineffectiveness (Panteli \& Sockalingam, 2005; Rose \& Shoham, 2004). Although some studies have found that these two types of conflict affect different aspects of organisational performance such as decision creativity, team commitment and knowledge sharing, similar results have not been found across organisations (Rose et al., 2007). Meanwhile, a metaanalysis suggests that the results of conflict on outcomes are 
equivocal (De Dreu \& Weingart, 2003). These inconsistent results have prompted researchers to identify certain interactive variables (e.g. trust) involved in the different dimensions of conflict that impact firm performance within alliance partnerships (Langfred, 2004).

Inter-partner trust within an alliance partnership refers to 'a state of a positive, confident though subjective expectation regarding the behaviour of somebody or something in a situation which entails risk to the trusting party' (Panteli \& Sockalingam, 2005, p. 600). Trust can sustain relationships between alliance members by facilitating mutually sharing and expectation (McEvily \& Tortoriello, 2011; Ng \& Chua, 2006; Xue, Lu, Shi, \& Zheng, 2018) to reduce the transaction costs and enhance their competitiveness (Doney \& Cannon, 1997; Dowell, Morrison \& Heffernan, 2015; Liu, Tao, Li, \& El-Ansary, 2007; Wu et al., 2017). McAllister (1995) distinguishes between cognitive and affective trust, which have been two generally accepted dimensions of trust across inter-organisational level. Cognitive trust is grounded in inter-partner reliability and competence. It is 'an instrumental inference that one makes from information about the other's behaviour under specific circumstances' (Chua, Ingram, \& Morris, 2008, p. 437). Cognitive trust is seen as 'from the head' (Chua et al., 2008), more special and less superficial in the context of cooperative activities than emotional trust. It involves a calculative and instrumental assessment, and a judgement based on the evidence of another's competence and reliability (Dowell et al., 2015). Information exchange is the critical drivers to establish cognitive trust between partners (Williams Middleton \& Nowell, 2018), such that cognitive assets are virtually determined by intensive communication, specific conflict resolution and even mutual sympathy (Akrout \& Diallo, 2017). In contrast, affective trust is grounded in mutual care and concern between alliance partners, present when firms care about 'the welfare of their partners and believe in the intrinsic virtue of such relationships' (Chua et al., 2008, p. 437). Affective trust involves empathy, rapport and self-disclosure, which is seen as 'from the heart' (Chua et al., 2008). Affective trust requires more emotional investment and is more enduring and generalisable across situations than cognition-based trust (Lewicki \& Bunker, 1996). These two types of trust align with a broader distinction between two basic sets of dimensions that differ experientially in social psychology [i.e. competence (intentional or volitional willingness) and warmth (perceptual or attitudinal expectation) (Fiske, Cuddy, \& Glick, 2007; McEvily \& Tortoriello, 2011)]. Extant research recognises the different nature and antecedents of different types of conflicts (Akrout \& Diallo, 2017; Rezvani, Barrett, \& Khosravi, 2018), and their effects at the individual level (e.g. Holste \& Fields, 2005; Levin \& Cross, 2004; Lucas, 2005; Ng \& Chua, 2006; Webber \& Klimoski, 2004; Wilson, Straus, \& McEvily, 2006) as well. However, few studies have examined the effects of these two types of trust and their differences in the interorganisational context. Just as McAllister (1995) advocates, theories about trust in an organisational context should be complemented by empirical research. Therefore, it is imperative and would be intriguing to differentiate between these two types of trust and examine their interactions with different types of conflicts in a relatively more complex context of inter-organisational partnerships (e.g. coopetition).

\section{Conflict-trust interactions as coopetition}

Within an alliance, inter-partner relationship management is vague, complex, non-routine-based and requires partner firms to interact on a decision platform. Because of the increasing importance of this relationship, conflict and trust have become the critical factors to fuel partners' interactionbased performance in global marketplace (Celuch, Bantham, \& Kasouf, 2011). Theoretical streams have made significant efforts to develop the notion of 'co-existence of conflict-trust'. According to social exchange theory (SET), trust is 'the fundamental principle of social exchange and the backbone of interpersonal and inter-organizational relationships' (Khalid \& Ali, 2017, p. 492), and the intense exchanges lead to the generation of the solution for the trust-conflict paradox, in that efficient enhancement of exchange would increase cooperative performance effectively (Das \& Teng, 2002; Ertürk \& Vurgun, 2015; Khalid \& Ali, 2017). Therefore, balancing conflict and trust are increasingly important in exchange-based alliances (Celuch et al., 2011; Wu et al., 2017). Drawing on the discussion around the 'inter-partner relationship' theme in social exchange literature, relationship marketing theory (RMT) makes efforts to form efficient mechanisms for managing complex and dynamic partnership in relational exchange (Katsikeas, Skarmeas, \& Bello, 2009), inter-partner conflict (Bai, Sheng, \& Li, 2016; Yang et al., 2017) and trust-based cooperation (Akrout \& Diallo, 2017; Doney\& Cannon, 1997; Jeffries \& Reed, 2000; Liu, Li, Tao, \& Wang, 2008). Relationship marketing theory suggests that trust and conflict cannot simply be regarded as good or bad, rather resolving the complex interactions between different dimensions of trust and conflict is critical to achieving better relationship marketing performance (Celuch et al., 2011; Ettlie, Tucci, \& Gianiodis, 2017). Relationship marketing scholars argue that conflict can often harm trust, whereas trust could help in resolving conflict (Yang et al., 2017). Although there is increasing attention on the investigation of the trust-conflict linkage, further assessment is needed to specify the interactions between trust and conflict, given their complexities (Bai et al., 2016). Grounding form RMT, commitment-trust theory (CTT) of Morgan and Hunt (1994) developed a key mediating variable model to reveal the complex process among exchange, trust, commitment and conflict in relationship marketing. Commitment-trust theory suggested that trust-based commitment is central in establishing, developing and maintaining a successful relational exchange between alliance partners, and the trustdriven relationship commitment may facilitate the interpartner acquiescence, propensity to leave and stable cooperation (Morgan \& Hunt, 1994). Following the CTT, trust refers to the willingness to rely on an exchange partner in whom one has confidence grounded on shared value, communication and opportunistic behaviour (Morgan \& Hunt, 1994), but the firm within a partnership will have to 
undertake high-risk and coordinated behaviours. In other words, conflict would often occur in cooperative actions, forming typical interrelations between them (Morgan \& Hunt, 1994).

Inspired by the above critical theoretical lens, the interaction between conflict and trust needs to be further assessed in terms of their implications for value creation. Prior literature has argued that conflict and trust could be the co-existing opposites in interaction between firms that can be managed in an integrated framework to drive firm performance growth (e.g. Langfred, 2004; Parayitam \& Dooley, 2009; Wu et al., 2017). For example, Parayitam and Dooley (2007) explored the moderating effect of trust (affective and cognitive) on the linkage between conflict (cognitive and affective) and decision quality, finding that cognitive trust is the key to fortifying the benefits of cognitive conflict and that affective trust is the panacea for the ills of cognitive conflict. Parayitam and Dooley (2009) examined how different dimensions of trust moderate the relationship between different conflict and strategic decision-making issues, suggesting that cognitive conflict and cognitive trust are far more important than affective conflict and affect-based trust in strategic decision-making teams. Other than these efforts, the literature has focused exclusively on how firms manage negative and dysfunctional emotion-based (or affective) conflict (e.g. Amason, 1996; Anderson \& Narus, 1984; Antia, Zheng, \& Frazier, 2013; Simons \& Peterson, 2000), positive and functional task-based (or cognitive) trust (e.g. Zaheer, McEvily, \& Perrone, 1998; Chowdhury, 2005) and dyadic effects (e.g. Wu et al., 2017) in separate domains, treating the interaction between trust and conflict as an either/or game. Because of the different dimensions of trust and conflict, interactions between them can be more holistic and dynamic with complex interactive effects acting as opposites-in-unity impacting firm performance within an alliance partnership (Chen, 2008; Li, 2008, 2012). Thus, trust and conflict should be taken as two orthogonal dimensions rather than two opposite poles of a single continuum; this is the both/and version of coopetition (Luo, 2004).

Starting from the coopetition perspective, Chen (2008) argued that the two opposites (i.e. cooperative and competitive elements) in coopetition may be 'all-inclusive' relationships, referred to as the trans-paradox. These paradoxical opposites always exist within alliance partnerships and lead to the holistic and dynamic interactions of coopetition (Bengtsson \& Kock, 2000; Brandenburger \& Nalebuff, 1996). Following this logic, trust represents the foundation of cooperation, consisting of friendliness because of common interests; conflict reflects the forces of competition, consisting of hostility because of the private interests of partners. We treat trust and conflict as complementary elements in balance with holistic multi-dimensional and comprehensive 'spatial' content creating a dynamic multi-phase and nonlinear temporal process ( $\mathrm{Li}, 2008)$. This view is 'based upon the simultaneous consideration of both sides of one thing and their possible mutual conversions and synergies'
(Fang, 2012) and is therefore consistent with the true spirit of the coopetition perspective (Chen, 2008). The trans-paradox of coopetition provides a powerful framework to integrate conflict and trust into unity, and offers an effective way to interpret the interactions between the sub-dimensions of trust and conflict in the configuration of the proper matches between different dimensions of trust and conflict in previous firm performance within partnerships.

\section{Hypotheses development}

As suggested by previous studies (Bai et al., 2016; Celuch et al., 2011; Ettlie et al., 2017; Wu et al., 2017), conflict and trust should be explored in-depth as co-existent in an integrated framework at the inter-organisational level. However, inter-partner relationships are often complex, dynamic and multifaceted along with the deepening of cooperation. Particularly, in different conditions or cooperative stages, not only conflict would perform differently, but also trust would change itself (Wu et al., 2017). In this situation, the trust-conflict interactions may produce heterogeneous patterns and outcomes. According to the trans-paradox framework of coopetition, trust and conflict could interact in both holistic and dynamic manner and generate different effects as a wholeness (Chen, 2008; Li, 2014).

In particular, trust (cognitive and affective) often plays its roles in objectively intentional willingness about competence and subjectively attitudinal expectation about emotions (Dowell et al., 2015; Williams Middleton \& Nowell, 2018), whereas conflict (task and emotional) performs on the basis of its different focus on specific affairs or problems about mutual task, and uncomfortable feelings about tensions of non-expectations (Chen \& Ayoko, 2012; Hood et al., 2017; Parayitam \& Dooley, 2009). When different types of trust and conflict co-exist in certain stages of the cooperative process, their complex interactive patterns would generate differentiated effects (Wu et al., 2017). For example, cognitive trust and task conflict reflect the objective judgements of cooperative affairs across interactive processes between partners, whereas affective trust and emotional conflict largely arise from subjective emotional tensions between partners. Considering such a diversity of sources, the complex interaction they create would generate complex outcomes rather than the 'either positive or negative' ones (Amason, 1996; Kalkman \& De Waard, 2017). In turn, there might be more possibilities to facilitate beneficial and/or harmful effects on a firm's performance, within an alliance partnership, thus a duality may enter into an integrated, harmonious trust-conflict relationship. (Chen, 2008; Li, 1998, 2014).

Thus, echoing the call that trust-conflict interaction should be explored in-depth in inter-organisational contexts (Bai et al., 2016; Langfred, 2004; Parayitam \& Dooley, 2009; Wu et al., 2017), we intend to reveal the micro-nature of interactions between trust and conflict by proposing that different types of trust and conflict would interact in holistic and dynamic manners. Specifically, this study constructs a 


\begin{tabular}{|c|c|c|}
\hline Emotional conflict & $\begin{array}{l}\text { Coupled pattern } \\
\text { H1: Positive }\end{array}$ & $\begin{array}{l}\text { Dysfunctional pattern } \\
\text { H3: Negative }\end{array}$ \\
\hline \multirow[t]{2}{*}{ Task conflict } & $\begin{array}{l}\text { Mismatched pattern } \\
\text { H4: Negative }\end{array}$ & $\begin{array}{l}\text { Compatible pattern } \\
\text { H2: Positive }\end{array}$ \\
\hline & Affective trust & Cognitive trust \\
\hline
\end{tabular}

Source: Authors' own work

FIGURE 1: Conceptual model.

matrix to break down the different dimensions of trust and conflict, and discuss the impacts of their different interacting patterns, namely coupled, dysfunctional, mismatched and compatible interactions in the firms' performance within alliance partnerships (Figure 1).

\section{Positive patterns of coopetition and performance}

Coupled interactions refer to well-matched interactions between emotional conflict and affective trust. Emotional conflict tends to be subjectively attitudinal psychological and focuses on 'inter-personal incompatibilities or disputes and typically provokes hostility, distrust, cynicism, apathy and other negative emotions' (Panteli \& Sockalingam, 2005). Independent emotional conflict can promote divides, diminish trust and weaken relationships, which decreases open communication, knowledge sharing and ultimately knowledge creation within cooperative partnerships (Amason \& Schweiger, 1994). However, the co-existence of emotional conflict and affective trust may reverse the negative effects on its outcomes. Affective trust arises from the heart, involving empathy, rapport and self-disclosure in the psychological aspects (Chua et al., 2008). It is effective to coordinate emotional tensions by attitudinal warmth to build harmonious climates relevant to affection. Because of the perceptual expectation, affective trust could guide two partners to make efforts towards positive actions for their co-development. In addition, the existence of emotional conflict may make members pay more attention to the potential conflicting risks of conflict in the cooperation when partners have to increase the emotional (or affective) trust and relationship investments to balance negative conflict (Yen et al., 2017). In this dynamic co-existing status, affective trust and emotional conflict are loosely coupled, and they are interdependent and form a totality in the trans-paradox as the 'middle-way' that traditional Chinese philology has termed (Chen, 2002). Such an interactive pattern facilitates better understanding of each other's mindset between two partners to achieve agreement and a common direction that are beneficial to alliance stability, and thus creates shared values for cooperative performance, ideas exploration, open communication, intensive cooperation motivation (Parayitam \& Dooley, 2009), as well as the co-development of knowledge, the acquisition and leveraging of knowledge and the generation of internal knowledge (Park et al., 2014).
Compatible interactions are well-balanced interactions between task conflict and cognitive trust. Task conflict focuses on task and judgemental differences regarding the best solutions for achieving cooperative objectives. A high level of task conflict means two partners disagree about task goals, key decision areas and the appropriate choice of action (Panteli \& Sockalingam, 2005). When task conflict occurs within cooperation, partner members compete over the distribution of resources, argue about procedures and policies and disagree on the interpretation of facts regarding cooperative tasks or objectives, actions that have considerable negative effects on the development of sustainable cooperation and better performance outcomes (Wit et al., 2016). In this situation, it has been suggested that trust is the remedy to counteract the negative aspects of task conflict (Simons \& Peterson, 2000). In particular, cognitive trust relies on the competence of the members and their intentional or volitional willingness. The competence-based trustworthiness could provide cues for how to process, interpret and act upon exchanged information between partners. Meanwhile, such trust may increase partners' commitment to the shared direction for task-related efforts (Morgan \& Hunt, 1994), and enable partner members to use diverse skills and to be more creative in defining and solving task-related problems (Parayitam \& Dooley, 2009), and thus have the potential to decrease the negative effects of conflict and facilitate cooperative task achievement (Morgan \& Hunt, 1994; Parayitam \&Dooley, 2007). The intentional willingness of cognitive trust could also increase firms' confidence in resolving the problems of task, while task conflict stimulates the intensive communication and ideas generation for best conflict solutions. Therefore, both task conflict and cognitive trust facilitate the equal conversation about objective and specific difficulties or troubles, and thus form well-compatible interactions:

Hypothesis 1: The interaction between emotional conflict and affective trust, acting as a coupled pattern of coopetition, positively impacts firm cooperative performance within alliance partnerships.

Hypothesis 2: The interaction between task conflict and cognitive trust, acting as a compatible pattern of coopetition, positively impacts firm cooperative performance within alliance partnerships.

\section{Negative patterns of coopetition and performance}

A dysfunctional pattern refers to the interaction between emotional conflict and cognitive trust. As emotional conflict arises from 'interpersonal tensions and is largely emotional in nature' (Parayitam \& Dooley, 2009, p. 1), it creates climates or negative attitudes that deteriorate into conflict (e.g. confronting, competition and destructive arguments) within inter-partner cooperation by concentrating on disagreements between partners (Rose et al., 2007). Emotional conflict is the emotional or psychological hostility associated with joint values, cognition and subjective judgement according to past interactive experience, whereas cognitive trust is the faith in each other's reliability and competency, and intentional willingness for resolving 
emergent problems, achieving task goals and maintaining dyadic integrity under specific circumstances (McEvily \& Tortoriello, 2011; Williams Middleton \& Nowell, 2018). Emotional conflicts arise from divergences or disagreements among partners, and create vague and negative emotional reactions in the working environment (Rezvani et al., 2018). Such conflicts can hardly provide accurate or specific signals and/or cues about 'what needed to be resolved', and thus reduce the possibility and effectiveness of a resolution (Jehn, 1997). Although cognitive trust would strengthen commitment, increase communication and resolve objective conflicts in confidence (McAllister, 1995; Ng \& Chua, 2006; Parayitam \& Dooley, 2009), the rational competence-based and/or volitional actions brought about by this kind of trust could not resolve the complex emotional conflict with irrational reasoning and vague task solutions (Jehn, 1997; Thomas, 1992).

Mismatched interactions between task conflict and affective trust are the negative patterns in coopetition that hurt alliance partnerships and cooperative performance. Task conflict exists when partner members have disagreements on motivation, decisions, choices and other issues (Pelled, Eisenhardt, \& Xin, 1999). As task conflict is 'micro works/ problem' grounded, it facilitates divergent thinking and triggers 'multiple perspectives being brought to bear on decision making and the consideration of diverse aspects of the issue under debate' (Panteli \& Sockalingam, 2005, p. 603). Based on emotional investment, affective trust, on the other hand, is more subjective and caring, and could be regarded as warmth in the cooperative process (Fiske et al., 2007; McEvily \& Tortoriello, 2011). It is thus less special and more superficial in the context of partnership than cognitive trust (Chua et al., 2008).

In the cooperative process, the emergence of task conflict necessitates the resolving of difficulties and problems as the central scheme for partner members aiming to achieve cooperative goals (Jehn, 1995). In this situation, the focal firm's needs for volitions and confidence from the partner firms are increased, and both parties should act rather than provide mere affective support (e.g. empathy and rapport) and disclose an attitude of positive expectation about cooperative goals. In its essence, affective trust, combined with competence-based cognitive trust, would be more enduring and applicable to different situations in reducing emotional misconduct (Jehn, 1997; Parayitam \& Dooley, 2007), yet it would be less effective in facilitating the solving of task-focused conflict (Drolet \& Morris, 2000). Specifically, affective trust with an attitude of warmth could not provide compatible views, ideas and opinions of partner members' decisions on resolving task conflict (Han \& Harms, 2010), which makes it hard for the focal firm to match specific objective task conflict at the same level to facilitate the taskfocused resolutions.

Hypothesis 3: The interaction between emotional conflict and cognitive trust, acting as a dysfunctional pattern of coopetition, negatively impacts firm cooperative performance within alliance partnerships.
Hypothesis 4: The interaction between task conflict and affective trust, acting as a mismatched pattern of coopetition, negatively impacts firm cooperative performance within alliance partnerships.

\section{Methodology Samples and data collection}

We chose Chinese data to test our research hypotheses. China is the largest emerging market (Cheung, Kong, Tan, \& Wang, 2015; Hua, Teng, \& Ouyang, 2018) and has a fast-growing economy ( $\operatorname{Lin} \& \mathrm{Xu}, 2015)$, so it has the best potential to provide an ideal research setting for two or three reasons. Firstly, high competition, technological resources scarcity and immature institutional business system cause more challenges for China's firms against the globalisation background (Li \& Peng, 2008; Li, Peng, \& Macaulay, 2015; Peng, 2003). Strategic alliance, as typical cooperative mode, has become an important competitive strategy in China' firms to confront threats and challenges, in which consequently alliance partnership management has gradually become the critical focus to facilitate successful strategic alliance. The increasing volume of strategic alliances and the importance of alliance partnership management in China could provide a good empirical setting for this study. Secondly, given a strong culture of guanxi (or relationship or ties), Chinese managers handle inter-partner relationship in a more indirect yet balancing manner (Li, 2012). This 'middleway philosophy' from the traditional Chinese culture (Chen, 2008; Li, 2014) often determines managers' behaviours and/ or attitudes about managing partnership. Because trust and conflict are relative opposites across partnerships, this middle-way mindset guides managers to balance and integrate opposites as the trans-paradox (Chen, 2008). This philosophy is beneficial to reveal the complex interactions of trust-conflict, going beyond extant research treating them as the simple multiplication of two separate constructs. Therefore, in the China context, this different philosophy across firm practices is likely to provide new findings and further extend and enrich extant theoretical research. Thirdly, as growing economy of China in the world, more international firms go into the Chinese market. It is critical help from multinational firms know more about 'what is going on there' (Meyer, 2006), which would provide important knowledge for those firms to understand Chinese business philosophy, properly establish alliances and efficiently manage partnership.

This study is exploratory research with quantitative method to empirically examine the effects of different interactions of conflict and trust on the focal firm performance within partnerships. To ensure powerful empirical evidences by quantitative analysis for the issue, the questionnaire-based survey instrument could be employed in the organisational and strategic management fields (Gerbing \& Anderson, 1988). In line with the approach, we conducted questionnairebased interviews to obtain sample data related to conflict, trust and performance within alliance partnerships. The first version of the questionnaire was developed by 
reviewing literature and then adapting the measurements from previous research studies. The translation and backtranslation technique were used to maintain the crosscultural equivalence of the interview questionnaire mechanisms (Yang et al., 2017). In addition, we sought modification advice from two executives and two academic scholars and polished our questionnaire to make sure that all items could be understood accurately by Chinese respondents and that the measurements reflect the Chinese business environment. A pilot study of two firms in Xi'an of Shaanxi province was conducted and the two responses were excluded from the final sample. We finalised the questionnaire based on all feedback and extensive discussion.

The survey was conducted in five provinces (Beijing, Shanghai, Shaanxi, Henan and Guangdong) which cover a broad geographic region of China, ensuring to reduce system error caused by regional economies and cultures. Of the five provinces, Beijing located in the northern region, is the capital of China as political centre, which has a high gross domestic product (GDP) growth and population of firms. Shanghai is the economical centre with a high degree of internationalisation of China, locating in the eastern coastal region. Guangdong is the largest southern provinces in China, which is the most typical reformed and open region with high GDP growth in past decades. Henan is the largest in acreage and the most populous province in the middle of China, representing the economic activity in the middle geographical region of China. Shaanxi is the most typical western provinces in China, which is treated as the most important engine driving economic development of China' western region in national long plans.

We selected China's manufacturing industry to collect our data because this industry has the largest volume of firms and is also the first large industrial type area in China where agriculture and service reigned. The sampling frame was randomly generated from local governmental departments in five regions (e.g. the committee of industrial park, the committee of economic development zone), which includes more than 1000 firms with contact information. After contacting these firms by email or telephone, 800 firms will participate in the survey. Then we filed, interviewed or emailed the questionnaire to the participants with an explanation of the objectives and requirements of this survey and a promise that all responses would be confidential and used for academic studies only. We required that the respondents filling in the questionnaire must be the senior executives such as chief executive officers (CEOs), chief operating officers (COOs) or chief financial officers (CFOs) with least 3 years' management experiences in the target firms because they are more familiar with their firm situation of cooperation and performance in order to give real and accurate information in this high-quality questionnaire. Finally, 614 firms gave back the questionnaires, of which 124 responses were excluded because of data or information deficiencies, resulting in 490 complete and valid questionnaires and an effective response rate of $76.75 \%$. Our final sample includes firms involved in electronics, machinery, pharmaceutics and the processing industry. To ensure the validity of the sample, from non-response bias was checked by $t$-tests and chi-square tests according to firm size and age. Both test results were insignificant, which suggests that non-response bias is not a problem. Harman's one-factor test was also conducted for all items to prove no common method bias in this study (Podsakoff, Mackenzie, Lee, \& Podsakoff, 2003).

\section{Measurement}

All variables (see Table 1), except those stated otherwise, were measured on a five-point Likert scale, ranging from

TABLE 1: Construct reliability and validity.

\begin{tabular}{|c|c|c|c|}
\hline Variable & Item & ms & $\begin{array}{c}\text { Factor } \\
\text { loadings }\end{array}$ \\
\hline \multirow{4}{*}{$\begin{array}{l}\text { Emotional conflict } \\
\text { (AVE = 0.657; } \\
\text { Cronbach's alpha = } \\
\text { 0.873; C.R. }=0.883 \text { ) }\end{array}$} & (1) $\underset{r}{T}$ & $\begin{array}{l}\text { To what frequency was friction present in your } \\
\text { relationship with the partner firm. }\end{array}$ & 0.667 \\
\hline & (2) & $\begin{array}{l}\text { How much anger is present in your relationship } \\
\text { with the partner firm. }\end{array}$ & 0.787 \\
\hline & (3) $T_{y}^{\top}$ & $\begin{array}{l}\text { To what extent are there personality clashes in } \\
\text { your relationship with the partner firm. }\end{array}$ & 0.887 \\
\hline & (4) $T^{\top}$ & $\begin{array}{l}\text { To what extent are there emotional tensions in } \\
\text { your relationship with the partner firm. }\end{array}$ & 0.881 \\
\hline \multirow{4}{*}{$\begin{array}{l}\text { Task conflict } \\
\text { (AVE = 0.714; } \\
\text { Cronbach's alpha = } \\
0.892 ; \text { C.R. = 0.909) }\end{array}$} & (1) $\begin{aligned} T \\
b \\
t\end{aligned}$ & $\begin{array}{l}\text { To what extent are there differences of opinions } \\
\text { between you and the partner firm regarding the } \\
\text { tasks. }\end{array}$ & 0.830 \\
\hline & (2) & $\begin{array}{l}\text { How often do people in your firm disagree with } \\
\text { people from the partner firm about the work. }\end{array}$ & 0.848 \\
\hline & (3) & $\begin{array}{l}\text { How often do you disagree with your partner } \\
\text { firm about the tasks they perform for you. }\end{array}$ & 0.878 \\
\hline & (4) & $\begin{array}{l}\text { How often do you and the partner firm disagree } \\
\text { about ideas regarding the collaboration tasks. }\end{array}$ & 0.822 \\
\hline \multirow{5}{*}{$\begin{array}{l}\text { Affective trust } \\
\text { (AVE = 0.551; } \\
\text { Cronbach's alpha = } \\
0.856 ; \text { C.R. }=0.859 \text { ) }\end{array}$} & (1) & $\begin{array}{l}\text { We have a sharing relationship with the partner } \\
\text { firm. We can both freely share our ideas, feelings } \\
\text { and hopes. }\end{array}$ & 0.695 \\
\hline & (2) $\begin{aligned} 1 \\
c \\
t\end{aligned}$ & $\begin{array}{l}\text { We can talk freely to the partner firm about } \\
\text { difficulties we are having at work and know that } \\
\text { the partner firm will want to listen. }\end{array}$ & 0.811 \\
\hline & (3) $\begin{array}{l}\mathrm{v} \\
\mathrm{v} \\
\mathrm{t}\end{array}$ & $\begin{array}{l}\text { We would both feel a sense of loss if one of us } \\
\text { was transferred and we could no longer work } \\
\text { together. }\end{array}$ & 0.713 \\
\hline & (4) 1 & $\begin{array}{l}\text { If we shared our problems with the partner firm, } \\
\text { we know that the partner firm would respond } \\
\text { constructively and caringly. }\end{array}$ & 0.786 \\
\hline & (5) & $\begin{array}{l}\text { We would have to say that we have both made } \\
\text { considerable emotional investments in our } \\
\text { working relationship. }\end{array}$ & 0.699 \\
\hline \multirow{5}{*}{$\begin{array}{l}\text { Cognitive trust } \\
\text { (AVE = 0.523; } \\
\text { Cronbach's alpha = } \\
0.873 ; \text { C.R. }=0.845 \text { ) }\end{array}$} & (1) & $\begin{array}{l}\text { The partner firm approaches its job with } \\
\text { professionalism and dedication. }\end{array}$ & 0.756 \\
\hline & (2) & $\begin{array}{l}\text { Given the partner firm's track record, we see no } \\
\text { reason to doubt its competence and preparation } \\
\text { for the collaboration. }\end{array}$ & 0.782 \\
\hline & (3) $\underset{j}{j}$ & $\begin{array}{l}\text { We can rely on this partner firm not to make our } \\
\text { job more difficult by careless work. }\end{array}$ & 0.731 \\
\hline & (4) & $\begin{array}{l}\text { Most people of the partner firm, even those who } \\
\text { are not my close friends, trust and respect me as } \\
\text { a co-worker. }\end{array}$ & 0.681 \\
\hline & (5) & $\begin{array}{l}\text { Other work associates of mine who must interact } \\
\text { with the partner firm consider this partner firm } \\
\text { to be trustworthy. }\end{array}$ & 0.660 \\
\hline \multirow{6}{*}{$\begin{array}{l}\text { Cooperative } \\
\text { performance } \\
\text { (AVE = 0.621; } \\
\text { Cronbach's alpha = } \\
0.914 ; \text { C.R. }=0.907 \text { ) }\end{array}$} & (1) $\begin{array}{l}\mathrm{V} \\
\mathrm{t}\end{array}$ & $\begin{array}{l}\text { We are satisfied with the overall performance of } \\
\text { the cooperation. }\end{array}$ & 0.826 \\
\hline & (2) & $\begin{array}{l}\text { The long-term objectives for which the } \\
\text { cooperation was established are being met } \\
\text { according to the schedule. }\end{array}$ & 0.839 \\
\hline & (3) $\begin{array}{l}1 \\
t\end{array}$ & $\begin{array}{l}\text { We are satisfied with the cooperation actions of } \\
\text { the partner firm. }\end{array}$ & 0.799 \\
\hline & (4) & $\begin{array}{l}\text { We had a very pleasant cooperation relationship } \\
\text { with the partner firm. }\end{array}$ & 0.760 \\
\hline & $(5)$ & We expanded our market through cooperation. & 0.760 \\
\hline & (6) & $\begin{array}{l}\text { We strengthened the enterprise's competitive } \\
\text { advantage through cooperation. }\end{array}$ & 0.739 \\
\hline
\end{tabular}

AVE, average variance extracted; C.R., construct reliability. 
' 1 ' representing 'strong disagreement' to ' 5 ' representing 'strong agreement'.

Following Geringer and Hebert (1991), Kale and Singh (2007) and Luvison and De Man (2015) and the feedback from the field interviews, we measured cooperative performance using six items (Cronbach's alpha $=0.914)$ to reflect the extent of cooperation the firms achieved according to the goal, such as market performance, competitive advantage and perceived satisfaction from the cooperative relationship. We used subjective measures, rather than financial indicators, because improvements in financial performance can be caused by irrelevant reasons and do not accurately reflect the extent of cooperation; moreover, better financial performance is often not the key goal of cooperation and many alliances aim to achieve more long-term interests and are willing to make sacrifices in short-term financial benefits.

Following Rose et al. (2007), Wit et al. (2016) and Yen et al. (2017), we measured emotional conflict (Cronbach's alpha = 0.873) using four items to capture personal conflict that can happen in relationships. We measured task conflict (Cronbach's alpha $=0.892$ ) that can arise from work tasks. Building on McAllister (1995), Parayitam and Dooley (2009) and Chen and Ayoko (2012), we used five items to measure affect trust (Cronbach's alpha $=0.856$ ), which refers to good expectations and confidence in partners' cooperation. We used five items to measure cognitive trust (Cronbach's alpha $=0.873)$, which refers to confidence in a partner's capability and professionalism.

To account for factors outside the model, several control variables were incorporated in the regression. (1) Firm size refers to the scale of a firm and was measured by the number of a firm's full-time employees (coded as 1: fewer than 50; 2 : 51-200; 3: 201-500; 4: 501-1000; 5: more than 1000) (Graves \& Langowitz, 1993). Larger firms often have greater market power than smaller firms in alliances. (2) Firm age was measured by years because the firm was established (coded as 1: fewer than 3 years; 2: 3-5 years; $3: 6-10$ years; 4 : $11-30$ years; 5 : more than 30 years). Older firms often have more resources and experience, endowing them with a higher status in alliances. (3) Form of cooperation reflects the alliance governance that shapes preferential organisational activities and decisions in alliances. According to the degree of closeness of cooperation in shareholding, the form of cooperation was coded as 1 for joint ventures, 2 for contractual cooperation and 3 for cross shareholdings. (4) Alliance experience, defined as the number of years of cooperation between the core firm and its alliance partner, presents the stability of the alliance (coded as 1: less than 1 year; 2 : $1-3$ years; 3: 3-5 years; 4: 5-10 years; 5: more than 10 years) (Heimeriks \& Duysters, 2007; Kale, Dye \& Singh, 2002). (5) Variety of cooperation, which refers to the scope of alliance activities, was measured by asking in how many aspects ( $R \& D$, manufacture and sales) the firms cooperate.

\section{Reliability and validity}

Reliability was assessed using the internal consistency method via Cronbach's alpha value (Cronbach, 1951; Nunnally, 1978). All constructs have a Cronbach's alpha greater than 0.856 (see Table 1), above the cut-off of 0.7, supporting the reliability of all theoretical constructs. We also computed the composite reliability (CR) to assess construct reliability. As reported in Table 1, all factors have CRs greater than 0.845 , above the cut-off of 0.7 , implying that the variance captured by the factor is significantly more than the variance indicated by the error components (Bagozzi \& Yi, 1988).

Construct validity was established using exploratory factor analysis (EFA). All indicators loaded onto their underlying construct during EFA using the principal components method with varimax rotation. The factor loadings are above 0.660 (see Table 1) and significantly above the requisite level of 0.6 (Fornell \& Larcker, 1981). The average variance extracted (AVE) was also computed and is greater than 0.50 for all constructs (see Table 1), indicating good convergent validity. We further assessed the discriminant validity of the constructs, which measures the extent to which the constructs are distinct. As suggested by Fornell and Larker (1981), the discriminant validity of a construct can be questioned if the square root of AVE for each construct with multiple items (in bold) is significantly greater than the off-diagonal elements (see Table 2). Taken together, these results show adequate discriminant validity for the measures in this study.

\section{Ethical considerations}

This article followed all ethical standards for carrying out research without direct contact with human or animal subjects.

\section{Analysis and results}

To address the research question, we used moderated regression models to test the interaction effects (Aiken \& West, 1991). To mitigate the potential threat of multicollinearity, we mean-centred each scale used to construct the interaction terms. The correlation matrix, means and standard deviations for the variables used in this study are given in Table 2 . Table 3 reports the regression analysis results step by step.

In Table 3, Model 1 only includes the control variables. Model 2 adds the main effects of emotional conflict, task conflict, affect trust and cognitive trust. Model 2 suggests that emotional conflict, task conflict, affect trust and cognitive trust can all influence cooperative performance, which supports the assertion that alliance mechanisms of trust and conflict can influence the performance of the focal firm through cooperation within alliance partnerships. After that, Models 3-6 add the interaction between emotional conflict and affective trust, the interaction between task 
TABLE 2: Correlation coefficients and average variance extracted values.

\begin{tabular}{|c|c|c|c|c|c|c|c|c|c|c|c|c|}
\hline Variable & Mean & Standard deviation & 1 & 2 & 5 & 6 & 7 & 8 & 9 & 10 & 11 & 12 \\
\hline 1. Firm age & 3.240 & 1.186 & N/A & - & - & - & - & - & - & - & - & - \\
\hline 2. Firm size & 1.790 & 0.808 & $0.148 *$ & $\mathrm{~N} / \mathrm{A}$ & - & - & - & - & - & - & - & - \\
\hline 3. Alliance experience & 3.320 & 1.177 & $0.511 * *$ & -0.1320 & N/A & - & - & - & - & - & - & - \\
\hline 4. Forms of cooperation & 2.000 & 0.365 & 0.0250 & 0.0340 & 0.1060 & N/A & - & - & - & - & - & - \\
\hline 5. Variety of cooperation & 1.290 & 0.619 & -0.066 & 0.024 & -0.003 & 0.086 & N/A & - & - & - & - & - \\
\hline 6. Emotional conflict & -0.018 & 0.724 & 0.038 & 0.027 & 0.006 & -0.131 & -0.034 & $0.811 \dagger$ & - & - & - & - \\
\hline 7. Task conflict & 0.024 & 0.837 & 0.018 & 0.029 & 0.034 & 0.002 & 0.003 & $0.499 * *$ & $0.845 \dagger$ & - & - & - \\
\hline 8. Affective trust & 0.000 & 0.792 & -0.018 & 0.038 & $0.151 *$ & 0.052 & 0.108 & -0.113 & $0.134 *$ & $0.742 \dagger$ & - & - \\
\hline 9. Cognitive trust & -0.057 & 0.811 & 0.017 & -0.137 & 0.136 & 0.01 & 0.047 & $-0.214 * *$ & -0.071 & $0.557 * *$ & $0.723 \dagger$ & - \\
\hline 10. Cooperative performance & -0.082 & 0.788 & -0.028 & -0.044 & $0.181 *$ & 0.061 & 0.064 & $-0.191 * *$ & -0.049 & $0.489 * *$ & $0.600 * *$ & $0.788 \dagger$ \\
\hline
\end{tabular}

$\dagger$, The diagonal elements are the root of average variance extracted value (AVE).

$*, p<0.05 ; * *, p<0.01 ; * * *, p<0.001$.

N/A, Not applicable.

Note: Number of samples is 490 .

TABLE 3: Results of regression analysis.

\begin{tabular}{|c|c|c|c|c|c|c|c|}
\hline \multirow[t]{2}{*}{ Variables } & \multicolumn{7}{|c|}{ Cooperative performance } \\
\hline & Model 1 & Model 2 & Model 3 & Model 4 & Model 5 & Model 6 & Model 7 \\
\hline \multicolumn{8}{|l|}{ Control variables } \\
\hline Firm age & $-0.327 * * *$ & -0.126 & $-0.129 *$ & -0.100 & -0.095 & -0.103 & $-0.137 *$ \\
\hline Firm size & -0.046 & -0.028 & -0.005 & -0.048 & -0.016 & -0.049 & 0.063 \\
\hline Forms of cooperation & $0.166^{* *}$ & $-0.130 *$ & $-0.155^{* *}$ & -0.094 & $-0.215 * * *$ & -0.089 & $-0.164^{* *}$ \\
\hline Alliance experience & $0.344 * * *$ & $0.156^{*}$ & $0.165 * *$ & $0.166 * *$ & 0.146 & $0.154^{* *}$ & $0.206 * * *$ \\
\hline Variety of cooperation & -0.014 & 0.076 & 0.054 & 0.088 & 0.041 & 0.098 & 0.052 \\
\hline \multicolumn{8}{|l|}{ Predictors } \\
\hline Emotional conflict (EC) & - & $-0.286 * * *$ & $-0.300 * * *$ & $-0.275 * * *$ & $-0.351 * * *$ & $-0.275 * * *$ & $-0.254 * * *$ \\
\hline Task conflict (TC) & - & $0.165^{* *}$ & $0.208 * * *$ & 0.116 & $0.264 * * *$ & 0.099 & -0.122 \\
\hline Affective trust (AT) & - & $0.319 * * *$ & $0.358 * * *$ & $0.306 * * *$ & $0.294 * * *$ & $0.340 * * *$ & $0.419 * * *$ \\
\hline Cognitive trust (CT) & - & $0.333 * * *$ & $0.336 * * *$ & $0.279 * * *$ & $0.402 * * *$ & $0.281^{* * *}$ & $0.235 * * *$ \\
\hline \multicolumn{8}{|l|}{ Interactions } \\
\hline$E C \times A T$ & - & - & $0.242^{* * *}$ & - & - & - & $0.417 * * *$ \\
\hline $\mathrm{EC} \times \mathrm{CT}$ & - & - & - & - & $-0.215 * * *$ & - & $-0.359 * * *$ \\
\hline $\mathrm{TC} \times \mathrm{CT}$ & - & - & - & - & - & 0.107 & $0.278 * * *$ \\
\hline \multicolumn{8}{|l|}{ Test results } \\
\hline$R^{2}$ & 0.158 & 0.443 & 0.341 & 0.310 & 0.459 & 0.448 & 0.541 \\
\hline$F$ Stats & $1.830 *$ & $3.673 * * *$ & $3.498 * * *$ & $3.251 * * *$ & $3.550 * * *$ & $2.966 * * *$ & $3.645 * * *$ \\
\hline
\end{tabular}

Note: Number of samples is 490 .

$*, p<0.05, * *, p<0.01 ; * * *, p<0.001$

conflict and affective trust, the interaction between emotional conflict and cognitive trust, and the interaction between task conflict and cognitive trust, respectively.

Further, we include all variables and interaction terms in Model 7 as full model to test the four hypotheses. As shown in full model, the results indicate that the interaction (as coupled pattern) between emotional conflict and affective trust is positively associated with cooperative performance for the focal firm ( $b=0.417, p<0.001)$. The interaction (as compatible pattern) between task conflict and cognitive trust positively impacts the focal firm's cooperative performance ( $b=0.278, p<0.001)$. Therefore, $\mathrm{H} 1$ and $\mathrm{H} 2$ were supported. In addition, the full model results show that the interaction (as dysfunctional pattern) between emotional conflict and cognitive trust is negatively associated with the cooperative performance of the focal firm $(b=-0.359, p<0.001)$, as is the interaction (as mismatched pattern) between task conflict and affective trust $(b=-0.244, p<0.001)$, thus supporting H3 and H4.
To test for an increase in $R^{2}$, an $F$-test was used to examine significant changes (Atuahene-Gima \& Li, 2006). As seen in Table 3, the increase in $R^{2}$ from Model 1 to Model 7 is 0.353 . This increase in $R^{2}$ is significant, indicating an improvement in overall model fit.

\section{Discussion}

Drawn on previous wisdoms of trust and conflict within partnerships (e.g. Akrout \& Diallo, 2017; Bai et al., 2016; Celuch et al., 2011; Das \& Teng, 2000; Dowell et al., 2015; Panteli \& Sockalingam, 2005; Xue et al., 2018; Yen et al., 2017), this study attempts to provide new insight into the trust-conflict interactions by distinguishing between the sub-dimensions of trust and conflict to construct an interactive matrix of four interactive patterns. In particular, the empirical results indicate that coupled patterns (interactions between emotional conflict and affective trust) and compatible patterns (interactions between task conflict and cognitive trust) increase firm performance within alliance partnerships, whereas dysfunctional patterns (interactions between emotional 
conflict and cognitive trust) and mismatched patterns (interactions between task conflict and affective trust) have negative effects.

\section{Theoretical implications}

Based on these endeavours, this study enriches our understanding of the complex nature of conflict-trust interactions as 'coopetition in duality', and specifies the heterogeneities in terms of the types and the associated effects of the configurations between different sub-dimensions of these two previously isolated continuums within a certain alliance relationship, and adds to previous research in the following ways.

Primarily, previous studies mainly employ a 'paradox as a problem' framing when explaining the effects of conflict and trust within an alliance (Amason \& Schweiger, 1994; Chen \& Ayoko, 2012; Das \& Teng, 2000; Rau, 2005; Wit et al., 2016), and examine their individual effects on the outcome variables or their 'moderation effects' on each other's impact. Our research goes one step further by adopting a 'trans-paradox as a solution' framing, and provides a relatively more holistic understanding regarding the inter-play between trust and conflict and their integrated 'coopetition' effects on firms' performance (Bengtsson \& Kock, 2000; Luo, 2007; Park et al., 2014; Xue et al., 2018).

Based on our primary contribution, our research further enriches current understanding of the conflict-trust tensions (i.e. complex nature, diversity and dynamics). In particular, the spirit of coopetition as trans-paradox (Chen, 2002, 2008; $\mathrm{Li}, 2008$ ) in wholeness recognises that the opposite elements (i.e. conflict and trust) are partially complementary (positive) if properly matched but partially contradictory (negative) if improperly combined. Our research validates this proposition by distinguishing the sub-dimensions of trust and conflict, specifying the four specific patterns of conflict-trust interactions, and more importantly, empirically illustrating that heterogeneities exist in their effect on firm performance. In this way, our research reveals the 'double-edged sword' effects of trust-conflict interactions that are contingent on the different types of configurations between their subdimensions, going beyond the 'trust or conflict as moderators on the "single-edged" effects of one another' logic that extant literature (e.g. Celuch et al., 2011; Han \& Harms, 2010; Hood et al., 2017; Liu et al., 2008; Panteli \& Sockalingam, 2005; Peterson \& Behfar, 2003; Rezvani et al., 2018; Wu et al., 2017) has considered.

In addition, previous investigations focus exclusively on advanced economies (e.g. Parayitam \& Dooley, 2007, 2009), and agree that trust always positively interacts with task-based (cognitive) conflict but usually negatively interacts with emotion-based (affective) conflict for alliance decision quality and decision commitment. Our research, based on the aforementioned shifted the framing paradigm, explores the relatively under-reached coopetition issue in
China's emerging economy, and suggests that affective trust could interact positively with emotion-based conflict and negatively with task-based conflict to affect alliance firm performance. This novel finding provides critical contextual knowledge about how conflict and trust interact to impact firm performance in developing economies, suggesting that the theoretical research has to pay more attention to the context-specific thinking for recognising and managing conflict-based and trust-based coopetition within an alliance partnership.

\section{Managerial implications}

This study has several important managerial implications. Firstly, our research implies that the trans-paradox thinking as middle-way philosophy is beneficial to managers to monitor the complexities and dynamics of trust-conflict interaction in alliance. In particular, trans-paradox thinking that is grounded in corporate culture and managerial cognition, embrace a synthesis of trust and conflict in specific dimensions and will be more likely to engender repertoires of syncretic rent-seeking performance than those that emphasise either isolated forces or interactive forces of trust and conflict as the uni-dimensional construct. Secondly, the nature of the conflict-trust interactions in the duality we delineate implies that managers should pay attention to balance trust and conflict in a holistic manner. Specifically, it is important for managers to cultivate emotions for inter-partner cooperation and foster skills for solving conflict in response to partners' varieties in trust and/or conflict, and try to keep the complementariness (coupled and compatible patterns) while a voiding the confliction (dysfunctional and mismatched patterns) based on the mindset of coopetition across long-term alliance partnership. Thirdly, several challenges such as the convergence of novel business models, emerging technologies and new customer demands in emerging economies necessitate the management of alliance partnerships. This study could provide potential implications to conduct managers' alliance practices such as the selection of partners with joint values, and the skillful management of cooperative partnerships through more informal mechanisms (e.g. favourable ties, affective care and stress-free atmosphere) which are particularly useful for increasing the cooperative quality of firms that operate in the business context of emerging economies.

\section{Limitation and future research}

This study has several limitations that future work should address. Firstly, we selected Chinese firms as the empirical setting to test our model, so the generalisability of our research findings should be further tested in other transitional economies and across different industries (Lin, Peng, Yang, \& Sun, 2009). Furthermore, future research should consider comparing advanced and transitional economies, which would enrich our knowledge of global alliance partnership management. Secondly, the cross-sectional data used in the study do not permit causal interpretation of the empirical findings. Therefore, to increase the reliability of these empirical findings, a longitudinal approach should be used 
in future research. Thirdly, how conflict and trust operate in coopetition as a duality (positive and negative) leading to both holistic and dynamic interactions might vary depending on the context. Future research needs to introduce more contingent factors, such as institutional environments, cultural features and formal alliance governance elements, into this framework.

\section{Conclusion}

This study applies the coopetition perspective to deconstruct the complex interactive nature of conflict and trust between partners, providing a sharp focus on how specific patterns of conflict (task and emotion) and trust (cognitive and affective) interact with each other in impacting the focal firms' performance within alliance partnerships. We find that coupled patterns (interactions between emotional conflict and affective trust) and compatible patterns (interactions between task conflict and cognitive trust) positively impact the focal firm's cooperative performance, whereas dysfunctional patterns (interactions between emotional conflict and cognitive trust) and mismatched patterns (interactions between task conflict and affective trust) negatively impact the focal firm's cooperative performance. Our findings indicate that trust and conflict in the context of coopetition may combine (or balance) in both primarily negative and primarily positive ways according to their different dimensions as duality, which adds new insights into how to manage the co-existence of conflict and trust in coopetition and implies that there are diverse ways to combine conflict and trust to achieve the most synergistic effect for firms within alliance partnerships.

\section{Acknowledgements}

We thank the grants from the National Natural Science Foundation of China (71672138, 71602157, 71402139), China Postdoctoral Science Foundation (2017M620461), the Soft Science Research Program in Shaanxi Province (2017KRM073, 2017KRM066) and the Fundamental Research Funds for the Central Universities (SK2017029).

\section{Competing interests}

The authors have declared that no competing interests exist. The views and opinions expressed in this article are those of the authors and do not necessarily reflect the official policy or position of any affiliated agency of the authors.

\section{Author's contributions}

H.S. designed this study and wrote a draft. Y.G. contributed to revise the theoretical part and further polished the whole contents of the manuscript. C.Z. collected the data and conducted empirical analysis in methodology.

\section{Funding}

This study is supported by the National Natural Science Foundation of China $(71672138,71602157,71402139)$, China
Postdoctoral Science Foundation (2017M620461), the Soft Science Research Program in Shaanxi Province (2017KRM073, 2017KRM066) and the Fundamental Research Funds for the Central Universities (SK2017029).

\section{Data availability statement}

Data sharing is not applicable to this article as no new data were created or analysed in this study.

\section{Disclaimer}

The views and opinions expressed in this article are those of the authors and do not necessarily reflect the official policy or position of any affiliated agency of the authors.

\section{References}

Aiken, L. S., \& West, S. G. (1991). Multiple regression: Testing and interpreting interactions - Institute for social and economic research. Journal of the Operational Research Society, 45(1), 119-120. https://doi.org/10.2307/2583960

Akrout, H., \& Diallo, M. F. (2017). Fundamental transformations of trust and its drivers: A multi-stage approach of business-to-business relationships. Industrial Marketing Management, 66(October), 159-171. https://doi.org/10.1016/j.indmarman. 2017.08.003

Amason, A. C. (1996). Distinguishing the effects of functional and dysfunctional conflict on strategic decision making: Resolving a paradox for top management teams. Academy of Management Journal, 39(1), 123-148. https://doi.org/ $10.2307 / 256633$

Amason, A. C., \& Schweiger, D. M. (1994). Resolving the paradox of conflict, strategic decision-making and organizational performance, International Journal of Conflict Management, 5(3), 239-253. https://doi.org/10.1108/eb022745

Anderson, J. C., \& Narus, J. A. (1984). A model of distributor's perspective or distributor-manufacturer working partnership, Journal of Marketing, 48(4), 62-74. https://doi.org/10.1177/002224298404800407

Antia, K. D., Zheng, X. U., \& Frazier, G. L. (2013). Conflict management and outcomes in franchise relationships: The role of regulation. Journal of Marketing Research, 50(5), 577-589. https://doi.org/10.1177/002224371305000502

Atuahene-Gima, K., \& Li, H. (2006). The effects of formal controls on supervisee trust in the manager in new product selling: Evidence from young and inexperienced salespeople in China. Journal of Product Innovation Management, 23(4), 342358. https://doi.org/10.1111/j.1540-5885.2006.00206.x

Bagozzi, R. P., \& Yi, Y. (1988). On the evaluation of structural equation models. Journa of the Academy of Marketing Science, 16(1), 74-94. https://doi.org/10.1007/ BF02723327

Bengtsson, M., \& Kock, S. (1999). Cooperation and competition in relationships between competitors in business networks. Journal of Business \& Industria Marketing, 14(3), 178-194.

Bengtsson, M., \& Kock, S. (2000). Coopetition' in business networks - To cooperate and compete simultaneously. Industrial Marketing Management, 29(5), 411-426. https://doi.org/10.1016/S0019-8501(99)00067-X

Bengtsson, M., \& Kock, S. (2014). 'Coopetition - Quo vadis? Past accomplishments and future challenges', Industrial Marketing Management, 43(2), 180-188. https://doi.org/10.1016/j.indmarman.2014.02.015

Bai, X., Sheng, S., \& Li, J. J. (2016). Contract governance and buyer-supplier conflict: The moderating role of institutions. Journal of Operations Management, 41(January), 12-24. https://doi.org/10.1016/j.jom.2015.10.003

Brandenburger, A., \& Nalebuff, B. (1996), Co-opetition. Currency Doubleday, New York, NY.

Celuch, K., Bantham, J. H., \& Kasouf, C. J. (2011). The role of trust in buyer-seller conflict management. Journal of Business Research, 64(10), 1082-1088. https:// doi.org/10.1016/j.jbusres.2010.11.011

Chen, M. J. (2002). Transcending paradox: The Chinese 'middle way' perspective. Asian Pacific Journal of Management, 19(2), 179-199. https://doi.org/10.1177/ 1056492607312577

Chen, M. (2008). Reconceptualizing the competition cooperation relationship A transparadox perspective. Journal of Management Inquiry, 17(4), 288-304. https://doi.org/10.1177/1056492607312577

Chen, M. J., \& Ayoko, O. B. (2012). Conflict and trust: The mediating effects of emotional arousal and self-conscious emotions. International Journal of Conflict Management, 23(1), 19-56. https://doi.org/10.1108/10444061211199313

Cheung, Y. L., Kong, D., Tan, W., \& Wang, W. (2015). Being good when being international in an emerging economy: The case of China', Journal of Business Ethics, 130(4), 805-817. https://doi.org/10.1007/s10551-014-2268-7

Chowdhury, S. (2005). The role of affect- and cognition-based trust in complex knowledge sharing. Journal of Managerial Issues, 17(3), 310-326. 
Chua, R. Y. J., Ingram, P., \& Morris, M. W. (2008). From the head and the heart: Locating cognition- and affect-based trust in managers' professional networks. Academy of Management Journal, 51(3), 436-452. https://doi.org/10.5465/ Academy of Managem
amj.2008.32625956

Cronbach, L. J. (1951). Coefficient alpha and the internal structure of tests. Psychometrika, 16(3), 297-334. https://doi.org/10.1007/BF02310555

Das, T. K., \& Teng, B. S., (2000). Instabilities of strategic alliances: An internal tensions perspective. Organization Science, 11(1), 77-101. https://doi.org/10.1287/orsc. 11.1.77.12570

Das, T. K., \& Teng, B. S. (2002). Alliance constellations: A social exchange perspective Academy of Management Review, 27(3), 445-456. https://doi.org/10.5465/amr. 2002.7389937

De Dreu, C. K., \& Weingart, L. R. (2003). 'Task versus relationship conflict, team performance, and team member satisfaction: A meta-analysis', Journal of Applied Psychology, 88(4), 741-749. https://doi.org/10.1037/0021-9010.88.4.741

De Dreu, C. K. W. (2006). When too little or too much hurts: Evidence for a curvilinear relationship between task conflict and innovation in teams. Journal of Management, 32(1), 83-107. https://doi.org/10.1177/0149206305277795

De Man, A. P., \& Roijakkers, N. (2009). Alliance governance: Balancing control and trust in dealing with risk. Long Range Planning, 42(1), 75-95. https://doi.org/ 10.1016/j.Irp.2008.10.006

Doney, P. M., \& Cannon, J. P. (1997). An examination of the nature of trust in buyerseller relationships. Journal of Marketing, 61(2), 35-51. https://doi.org/10.1177/ 002224299706100203

Dowell, D., Morrison, M., \& Heffernan, T. (2015). The changing importance of affective trust and cognitive trust across the relationship lifecycle: A study of business-tobusiness relationships. Industrial Marketing Management, 44(January), 119-130. https://doi.org/10.1016/j.indmarman.2014.10.016

Drolet, A. L., \& Morris, M. W. (2000). Rapport in conflict resolution: Accounting for how face-to-face contact fosters mutual cooperation in mixed-motive conflicts. Journal of Experimental Social Psychology, 36, 26-50. https://doi.org/10.1006/ jesp.1999.1395

Ertürk, A., \& Vurgun, L. (2015). Retention of IT professionals: Examining the influence of empowerment, social exchange, and trust. Journal of Business Research, 68(1) 34-46. https://doi.org/10.1016/j.jbusres.2014.05.010

Ettlie, J. E., Tucci, C., \& Gianiodis, P. T. (2017). Trust, integrated information technology and new product success. European Journal of Innovation Management, 20(3), 406-427. https://doi.org/10.1108/EJIM-12-2015-0128

Fang, T. (2012). Yin Yang: A new perspective on culture. Management and Organization Review, 8(1), 25-50. https://doi.org/10.1111/j.1740-8784.2011.00221.x

Fiske, S. T., Cuddy, A. J. C., \& Glick, P. (2007). Universal dimensions of social cognition: Warmth and competence. Trends in Cognitive Sciences, 11(2), 77-83. https://doi. org/10.1016/j.tics.2006.11.005

Fornell, C., \& Larcker, D. F. (1981). Evaluating structural equation models with unobservable variables and measurement error. Journal of Marketing Research 18(1), 39-50. https://doi.org/10.1177/002224378101800104

Gerbing, D. W., \& Anderson, J. C. (1988). Structural equation modeling in practice. Psychological Bulletin, 103(3), 411-423. https://doi.org/10.1037/0033-2909.103. 3.411

Geringer, J. M., \& Hebert, L. (1991). Measuring performance of international joint ventures. Journal of International Business Studies, 22(2), 249-263. https://doi.org/ 10.1057/palgrave.jibs.8490302

Graves, S. B., \& Langowitz, N. S. (1993). Innovative productivity and returns to scale in the pharmaceutical industry. Strategic Management Journal, 14(8), 593-605. https://doi.org/10.1002/smj.4250140803

Han, G., \& Harms, P. D. (2010). Team identification, trust and conflict: A mediation model. International Journal of conflict management, 21(1), 20-43. https://doi.org/ 10.1108/10444061011016614

Heimeriks, K. H., \& Duysters, G. (2007). Alliance capability as a mediator between experience and alliance performance: An empirical investigation into the alliance capability development process. Journal of Management Studies, 44(1), 25-49. https://doi.org/10.1111/j.1467-6486.2006.00639.x

Holste, J. S., \& Fields, D. (2010). Trust and tacit knowledge sharing and use. Journal of Knowledge Management, 14(1), 128-140. https://doi.org/10.1108/136732710 11015615

Hood, A. C., Cruz, K. S., \& Bachrach, D. G. (2017). Conflicts with friends: A multiplex view of friendship and conflict and its association with performance in teams. Journal of Business and Psychology, 32(1), 73-86. https://doi.org/10.1007/s10869016-9436-y

Shang, H., Zhang, T., \& Ouyang, P. (2018). Credit allocation and firm productivity under financial imperfection: Evidence from Chinese manufacturing firms. Emerging Markets Finance \& Trade, 54(5), 992-1010. https://doi.org/10.1080/1540496X. Markets Finance

Hunt, S. D., \& Morgan, R. M. (1994). 'Organizational commitment: One of many commitments or key mediating construct. Academy of Management Journal, 37(6), 1568-1587. https://doi.org/10.5465/256799

Ireland, R. D., Hitt, M. A., \& Vaidyanath, D. (2002). Alliance management as a source of competitive advantage. Journal of Management, 28(3), 413-446. https://doi. org $/ 10.1177 / 014920630202800308$

Jeffries, F. L., \& Reed, R. (2000). Trust and adaptation in relational contracting. Academy of Management Review, 25(4), 873-882. https://doi.org/10.5465/ amr.2000.3707747
Jehn, K. A. (1995). A multimethod examination of the benefits and detriments of intragroup conflict. Administrative Science Quarterly, 40(2), 256-282. https://doi. intragroup conflict. Ad
org/10.2307/2393638

Jehn, K. A. (1997). A qualitative analysis of conflict types and dimensions in organizational groups. Administrative Science Quarterly, 42(3), 530-557. https:// doi.org/10.2307/2393737

Kale, P., Dyer, J. H., \& Singh, H. (2002). Alliance capability, stock market response, and long-term alliance success: The role of the alliance function. Strategic Management Journal, 23(8), 747-767. https://doi.org/10.1002/smj.248

Kale, P., \& Singh, H. (2007). Building firm capabilities through learning: The role of the alliance learning process in alliance capability and firm-level alliance success. Strategic Management Journal, 28(10), 981-1000. https://doi.org/10.1002/ smj.616

Kalkman, J. P., \& De Waard, E. J. (2017). Inter-organizational disaster management projects: Finding the middle way between trust and control. International Journal of Project Management, 35(5), 889-899. https://doi.org/10.1016/j.ijproman. 2016.09.013

Katsikeas, C. S., Skarmeas, D., \& Bello, D. C. (2009). Developing successful trust-based international exchange relationships. Journal of International Business Studies, 40(1), 132-155. https://doi.org/10.1057/palgrave.jibs.8400401

Khalid, S., \& Ali, T. (2017). An integrated perspective of social exchange theory and transaction cost approach on the antecedents of trust in international joint ventures. International Business Review, 26(3), 491-501. https://doi.org/ 10.1016/j.ibusrev.2016.10.008

Langfred, C. W. (2004). Too much of a good thing? Negative effects of high trust and individual autonomy in self-managing teams. Academy of Management Journal, 47(3), 385-399. https://doi.org/10.2307/20159588

Levin, D. Z., \& Cross, R. (2004). The strength of weak ties you can trust: The mediating role of trust in effective knowledge transfer. Management Science, 50(11), 1477-1490. https://doi.org/10.1287/mnsc.1030.0136

Lewicki, R. J., \& Bunker, B. B. (1996). Developing and maintaining trust in work relationships. In R. Kramer \& T. Tyler (Eds.), Trust in organizations: Frontiers of theory and research (pp. 114-139). Thousand Oaks, CA: Sage.

Li, L., Jiang, F., Pei, Y., \& Jiang, N. (2017). Entrepreneurial orientation and strategic alliance success: The contingency role of relational factors. Journal of Business Research, 72(1), 46-56. https://doi.org/10.1016/j.jbusres.2016.11.011

Li, P. P. (1998). Toward a geocentric framework of organizational form: A holistic, dynamic and paradoxical approach. Organization Studies, 19(5), 829-861. https:// doi.org/10.1177/017084069801900506

Li, P. P. (2008). Toward a geocentric framework of trust: An application to organizationa trust Management and Organization Review, 4(3), 413-439. https://doi.org/ 10.1111/j.1740-8784.2008.00120.x

$\mathrm{Li}$, P. P. (2012). Toward an integrative framework of indigenous research: The geocentric implications of Yin-Yang Balance. Asia Pacific Journal of Management 29(4), 849-872. https://doi.org/10.1007/s10490-011-9250-z

Li, P. P. (2014). The unique value of yin-yang balancing: A critical response. Management and Organization Review, 10(2), 321-332. https://doi.org/10.1017/ S1740877600004228

Li, Y., \& Peng, M. W. (2008). Developing theory from strategic management research in China. Asia Pacific Journal of Management, 25(3), 563-572. https://doi.org/ 10.1007/s10490-007-9083-y

Li, Y., Peng, M. W., \& Macaulay, C. D. (2015). 'Market-political ambidexterity during institutional transitions', Strategic Organization, 11(2), 205-213. https://doi.org/ $10.1177 / 1476127012470403$

Lin, J. Y., \& Xu, J. (2015). The potential for green growth and structural transformation in China. Oxford Review of Economic Policy, 30(3), 550-568. https://doi.org/ 10.1093/oxrep/gru030

Lin, Z., Peng, M. W., Yang, H., \& Sun, S. L. (2009). How do networks and learning drive M\&As? An institutional comparison between China and the United States. Strategic Management Journal, 30(10), 1113-1132. https://doi.org/10.1002/ smj.777

Liu, Y., Li, Y., Tao, L., \& Wang, Y. (2008). Relationship stability, trust and relational risk in marketing channels: Evidence from China. Journal of Business \& Industria Marketing, 37(4), 432-446. https://doi.org/10.1016/j.indmarman.2007.04.001

Liu, Y., Tao, L., Li, Y., \& El-Ansary, A. I. (2007). The impact of a distributor's trust in a supplier and use of control mechanisms on relational value creation in marketing channels. Journal of Business \& Industrial Marketing, 23(1), 12-22. https://doi. org/10.1108/08858620810841452

Lucas, L. (2005). The impact of trust and reputation on the transfer of best practices. Journal of Knowledge Management, 9(4), 87-101. https://doi.org/10.1108/ 13673270510610350

Luo, Y. (2004). A co-opetition perspective of MNC-host government relations. Journa of International Management, 10(4), 431-451. https://doi.org/10.1016/j.intman. 2004.08.004

Luo, Y. (2007), A co-opetition perspective of global competition. Journal of World Business, 42(2), 129-144. https://doi.org/10.1016/j.jwb.2006.08.007

Luvison, D., \& De Man, A. (2015). 'Firm performance and alliance capability: The mediating role of culture', Management Decision, 53(7), 1581-1600. https://doi. org/10.1108/MD-09-2014-0580

Morgan, R. M., \& Hunt, S. D. (1994). The commitment-trust theory of relationship marketing. Journal of Marketing, 58(3), 20-38. https://doi.org/10.1177/0022242 99405800302 
McAllister, D. J. (1995). Affect and cognition-based trust as foundations for interpersonal cooperation in organizations. Academy of Management Journal, 38(1), 24-59. https://doi.org/10.2307/256727

McEvily, B., \& Tortoriello, M. (2011). Measuring trust in organisational research Review and recommendations. Journal of Trust Research, 1(1), 23-63.

Meyer, K. E. (2006). Asian management research needs more self-confidence. Asia Pacific Journal of Management, 23(2), 119-137.

Ng, K. Y., \& Chua, R. Y. J. (2006). Do I contribute more when I trust more? Differential effects of cognition- and affect-based trust. Management \& Organization Review, 2(1), 43-66. https://doi.org/10.1111/j.1740-8784.2006.00028.x

Nunnally, J. C. (1978). Psychometric theory. New York, NY: McGraw-Hill.

Panteli, N., \& Sockalingam, S. (2005). Trust and conflict within virtual interorganizational alliances: A framework for facilitating knowledge sharing. Decision Support Systems, 39(4), 599-617. https://doi.org/10.1016/j.dss.2004.03.003

Parayitam, S., \& Dooley, R. S. (2007). The relationship between conflict and decision outcomes. International Journal of Conflict Management, 18(1), 42-73. https:// doi.org/10.1016/j.jbusres.2008.02.006

Parayitam, S., \& Dooley, R. S. (2009). The interplay between cognitive- and affective conflict and cognition- and affect-based trust in influencing decision outcomes. Journal of Business Research, 62(8), 789-796. https://doi.org/10.1016/j.jbusres. 2008.02006

Park, B. J. R. Srivastava, M. K., \& Gnyawali, D. R. (2014). Walking the tight rope of coopetition: Impact of competition and cooperation intensities and balance on firm innovation performance. Industrial Marketing Management, 43(2), 210-221. https://doi.org/10.1016/j.indmarman.2013.11.003

Pelled, L. H., Eisenhardt, K. M., \& Xin, K. R. (1999). Exploring the black box: An analysis of work group diversity, conflict and performance. Administrative Science Quarterly, 44(1), 1-28. https://doi.org/10.2307/2667029

Peng, M. W. (2003). Institutional transitions and strategic choices. Academy of Management Review, 28(2), 275-296. https://doi.org/10.5465/amr.2003.9416341

Peterson, R. J., \& Behfar, K. J. (2003). The dynamic relationship between performance feedback, trust and conflict in groups: A longitudinal study. Organizationa Behavior \& Human Decision Processes, 92(1), 102-112. https://doi.org/10.1016/ S0749-5978(03)00090-6

Podsakoff, P. M., Mackenzie, S. B., Lee, J. Y., \& Podsakoff, N. P. (2003). Common method biases in behavioral research: A critical review of the literature and recommended remedies. Journal of Applied Psychology, 88(5), 879-903. https://doi.org/10.1037/ $0021-9010.88 .5 .879$

Rau, D. (2005). The influence of relationship conflict and trust on the transactive memories. Small Group Research, 36(6), 746-771. https://doi.org/10.1177/1046 496405281776

Rezvani, A., Barrett, R., \& Khosravi, P. (2018). Investigating the relationships among team emotional intelligence, trust, conflict and team performance. Team Performance Management: An International Journal, 25(1/2), 120-137. https:// doi.org/10.1108/TPM-03-2018-0019.
Rose, G. M., \& Shoham, A. (2004). Interorganizational task and emotional conflict with international channels of distribution. Journal of Business Research, 57(9), 942-950. https://doi.org/10.1016/j.jbusres.2006.11.007

Rose, G. M., Shoham, A., Neill, S., \& Ruvio, A. (2007), 'Manufacturer perceptions of the consequences of task and emotional conflict within domestic channels of distribution', Journal of Business Research, 60(4), 296-304. https://doi.org/ 10.1016/j.jbusres.2006.11.007

Simons, T. L., \& Peterson, R. S. (2000). Task conflict and relationship conflict in top management teams: The pivotal role of intragroup trust. Journal of Applied Psychology, 85(1), 102-111. https://doi.org/10.1037/0021-9010. of Applied

Thomas, W. (1992). Conflict and negotiation processes in organizations. In M. D. Dunnette (ed.). Handbook of industrial and organizational psychology (651-717). Palo Alto, CA: Consulting Psychology Press.

Webber, S. S., \& Klimoski, R. J. (2004). Client-project manager engagements, trust, and loyalty. Journal of Organizational Behavior, 25(8), 997-1013. https://doi.org/ $10.1002 /$ job.294

Williams Middleton, K., \& Nowell, P. (2018). Team trust and control in new venture emergence. International Journal of Entrepreneurial Behavior \& Research, 24(4), 882-910. https://doi.org/10.1108/IJEBR-01-2017-0048

Wilson, J. M., Straus, S. G., \& McEvily, B. (2006). All in due time: The development of trust in computer-mediated and face-to-face teams, Organizational Behavior \& Human Decision Processes, 99(1), 16-33. https://doi.org/10.1016/j.obhdp.2005. 08.001

Wit, F. D., Jehn, K. A., \& Scheepers, D. (2016). Task conflict in decisionmaking: The role of interdependent self-construal, stress and emotionality. Academy of Management Annual Meeting Proceedings, 2016(1), 12882. https://doi.org/10.5465/ambpp. 2016.12882abstract

Wu, G., Zhao, X., \& Zuo, J. (2017). Relationship between project's added value and the trust-conflict interaction among project teams. Journal of Management in Engineering, 33(4), 04017011.

Xue, J., Lu, S., Shi, B., \& Zheng, H. (2018). Trust, guanxi, and cooperation: A study on partner opportunism in Chinese joint-venture manufacturing, Journal of Business \& Industrial Marketing, 33(1), 95-106. https://doi.org/10.1108/JBIM-072016-0159

Yang, W., Gao, Y., Li, Y., Shen, H., \& Zheng, S. (2017). Different roles of control mechanisms in buyer-supplier conflict: An empirical study from China. Industrial Marketing Management, 65(August), 144-156. https://doi.org/10.1016/ jarketing Management,

Yen, D. A., Abosag, I., Huang, Y. A., \& Bang, N. (2017). Guanxi, GRX (ganqing, renqing, xinren) and conflict management in Sino-US business relationships. Industria Marketing Management, 66(October), 103-114. https://doi.org/10.1016/ jarketing Management,

Zaheer, A., McEvily, B., \& Perrone, V. (1998). Does trust matter? Exploring the effects of interorganizational and interpersonal trust on performance. Organization science, 9(2), 141-159. https://doi.org/10.1287/orsc.9.2.141 